University of Nebraska - Lincoln

DigitalCommons@University of Nebraska - Lincoln

Agronomy \& Horticulture - Faculty Publications

Agronomy and Horticulture Department

10-1976

\title{
Interactions Between Insects and Chemical Components of Sweetclover
}

\author{
G. R. Manglitz \\ United States Department of Agriculture \\ Herman J. Gorz \\ United States Department of Agriculture \\ Francis A. Haskins \\ University of Nebraska-Lincoln, fhaskins@neb.rr.com \\ W. R. Akeson \\ University of Nebraska-Lincoln \\ G. L. Beland \\ University of Nebraska-Lincoln
}

Follow this and additional works at: https://digitalcommons.unl.edu/agronomyfacpub

Part of the Plant Sciences Commons

Manglitz, G. R.; Gorz, Herman J.; Haskins, Francis A.; Akeson, W. R.; and Beland, G. L., "Interactions Between Insects and Chemical Components of Sweetclover" (1976). Agronomy \& Horticulture -- Faculty Publications. 277.

https://digitalcommons.unl.edu/agronomyfacpub/277

This Article is brought to you for free and open access by the Agronomy and Horticulture Department at DigitalCommons@University of Nebraska - Lincoln. It has been accepted for inclusion in Agronomy \& Horticulture -Faculty Publications by an authorized administrator of DigitalCommons@University of Nebraska - Lincoln. 


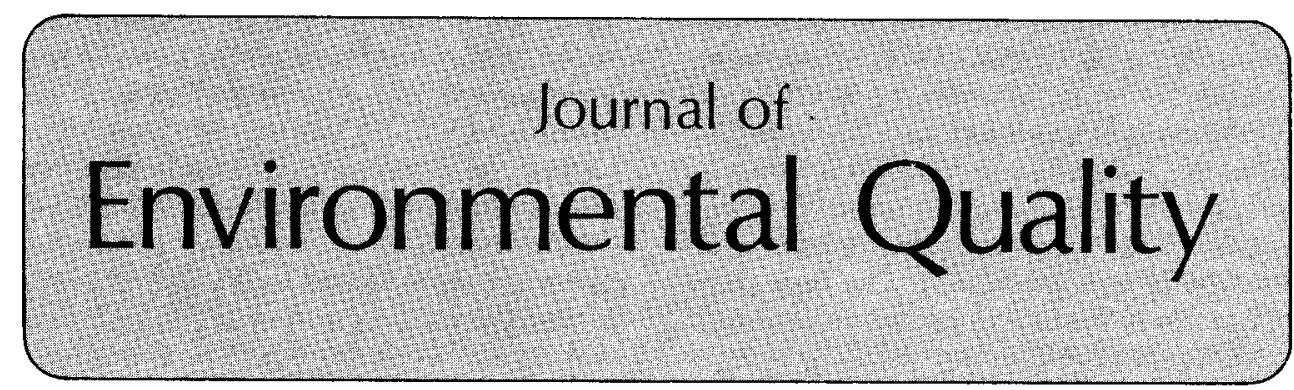

VOLUME 5 • OCTOBER-DECEMBER 1976 • NUMBER 4

\title{
REVIEWS AND ANALYSES
}

\section{Interactions between Insects and Chemical Components of Sweetclover ${ }^{1}$}

\author{
G. R. Manglitz, H. J. Gorz, F. A. Haskins, W. R. Akeson, and G. L. Beland ${ }^{2}$
}

\section{ABSTRACT}

This review concerns the relationship between chemical components found in sweetclover [Melilotus officinalis (L.) Pall. and $M$. alba Desr.] tissues and insects feeding on these tissues. Coumarin and its related compounds did not appear to influence the feeding of sweetclover aphids [Therioaphis riehmi (Börner)], pea aphids [Acyrthosiphum pisum (Harris)] or potato leafhoppers [Empoasca fabae (Harris)], however, these materials appeared attractive to sweetclover weevils (Sitona cylindricollis Fåhraeus) and to adult sweetclover root borers [Walshia miscecolorella (Chambers)]. Conversely the feeding of four species of blister beetles (Epicauta sp.) was inhibited by cis-o-hydroxycinnamic acid glucoside and coumarin, but was not affected by trans-o-hydroxycinnamic acid glucoside. An artificial method of feeding sweetclover weevils was used to bioassay substances extracted from sweetclover. Three classes of feeding stimulants were found: (i) three sugars (sucrose, glucose, and fructose); (ii) a chloroform-soluble stimulant(s) (possibly a lipid); and (iii) adenosine. Two feeding deterrents were found. Deterrent " $A$ " was partially characterized as a substituted phenolic compound, and deterrent " $B$ " was identified as the nitrate ion. The relative concentrations of the stimulant and deterrent substances in the resistant plants were found to change as the plant matured. Thus, no one substance is responsible for resistance throughout the life of the plant. In seedlings of resistant plants, the nitrate ion plays the principal role in resistance to weevil feeding, but in more mature plants resistance seems to result from the relative amounts of other deterrents and stimulants. It may be possible to use this knowledge to screen for resistance without using insects or to protect the plants artificially by increasing levels of deterring substances, such as nitrate ion, by means of fertilizer applications.

Additional Index Words: blister beetles, chemical nature of insect resistance, Melilotus alba, Melilotus infesta, Melilotus officinalis, pea aphids, plant resistance to insects, potato leafhopper, sweetclover aphid, sweetclover root borer, sweetclover weevil.

The interactions between plant-feeding insects and the chemical components of the plants upon which they feed are often complex and are always important to the survival of the insect. Studies of these interactions were reviewed from the viewpoint of evolution (13), host plart selection (29), and resistance of plants to insects (10). It is from the last of these viewpoints that we approach the present review. A better understanding of insect-plantchemical relationships could aid in the selection of resistant plants and possibly lead to other environmentally safe means of insect control. This review is confined to sweetclover-insect interactions because this is an area where much recent information has accumulated and because we have been closely associated with much of that work. Conclusions drawn from this review could well have application to other crop-insect relationships.

A number of insects attack and damage sweetclover [Melilotus officinalis (L.) Pall. and M. alba Desr.] plants. Most notable among them is the sweetclover weevil (Sitona cylindricollis Fåhraeus). The ideal way of controlling insects on a low cash value crop such as sweetclover is through the use of insect-resistant plants. It was the search for plant resistance and the desire to know why certain plants were resistant that led to most of the research discussed in this review.

Coumarin is one of the better known chemical substances associated with sweetclover. The first part of this review will be concerned with the influence of coumarin and its precursors in attracting several species of insects to sweetclover and with their resultant feeding behavior. In the second part, several chemical substances isolated from sweetclover are shown to influence feeding by the sweetclover weevil. Differences in the contents of these substances in the resistant species, Melilotus infesta Guss., and in a susceptible species, $M$. officinalis, are discussed.

\footnotetext{
${ }^{1}$ Contribution from the Agric. Res. Serv., USDA, and the Nebraska Agric. Exp. Stn., Lincoln. Published as Pap. No. $5005 \mathrm{~J}$. Ser., Nebraska Agric. Exp. Stn. and Contribution No 400 of the Dep. of Entomol., Univ. of Nebraska, Lincoln (UNL), NE 68583. The work reported was conducted under Proj. 17-27 and 12-27, Nebraska Agric. Exp. Stn. Received 3 Mar. 1976.

${ }^{2}$ Research Entomologist, ARS, USDA; Research Geneticist, ARS, USDA; Foundation Professor of Agronomy, UNL; former Assistant Professor of Agronomy, and former Instructor of Entomology, UNL, respectively.
} 


\section{COUMARIN AND RELATED COMPOUNDS IN HOST SELECTION}

\section{Coumarin Biosynthesis}

Although coumarin, as such, does not occur in intact sweetclover plants (17) it is formed rapidly in tissues that are disrupted as by the feeding of insects. The final steps in the biosynthetic pathway leading to coumarin in sweetclover are shown in Fig. 1. The first compound shown in the pathway, trans-o-hydroxycinnamic acid (trans-o-HCA) glucoside, is synthesized in very young leaves and is then partially converted to the corresponding cis isomer by the action of ultraviolet light (18). Thus, in intact plants grown in sunlight, the predominant compound present will be cis-o-hydroxycinnamic acid (cis-o-HCA) glucoside, but in plants grown in growth chambers equipped with lamps deficient in ultraviolet light (such as cool white fluorescent lamps), the predominant compound in the plant will be trans-o-HCA glucoside. In those plants with both a high content of cis-o-HCA glucoside and high activity of $\beta$-glucosidase (the enzyme that affects hydrolysis of cis-o-HCA glucoside), tissue disruption (such as that caused by insect feeding) results in rapid hydrolysis of the cis-o-HCA glucoside to yield cis-o-HCA which lactonizes spontaneously to form coumarin. However, no free coumarin formation would be expected during insect feeding on leaves containing only trans-o-HCA glucoside because the $\beta$-glucosidase in sweetclover does not hydrolyze the trans glucoside (21). Therefore, coumarin formation in sweetclover is not only dependent on the presence of the proper precursor and enzyme but also on the "activation" of the enzyme by tissue disruption. Since levels of $o$-HCA and $\beta$-glucosidase activity are under genetic control (14) near-isogenic lines that were high and low in $o$-HCA and enzyme were used in many of these studies. In some instances later in this paper, "high-coumarin" and "lowcoumarin" will be used to refer to plants high and Iow in content of the coumarin-related compounds just described.

\section{Blister Beetles}

The relationship which can exist between coumarin and its related compounds, and sweetclover insects is clearly exhibited by several species of blister beetles (Epicauta sp.). These beetles had long been observed as occasional inhabitants of sweetclover, but had never done any serious damage to that crop until low-coumarin cultivars were developed.

The four species of blister beetles tested not only fed preferentially on low-coumarin plants, but also were able to distinguish between plants differing in $\beta$-glucosidase activity when coumarin was released as a result of that activity. The cis isomer of $o$-HCA glucoside acted as a deterrent to beetle feeding, and coumarin also was a deterrent with an additive effect. In plants containing the enzyme, which was activated by beetle feeding, cis-o-HCA glucoside was hydrolyzed to yield the aglycone which quickly formed coumarin. When beetles that had fed on these plants were transferred to plants high in glucoside but lacking the enzyme, enough enzyme apparently remained on their mandibles (or palps) to convert the glucoside to coumarin. Moreover, plants grown under artificial light were high in the trans-o-HCA glucoside and lacked deterrent activity compared with sunlight-grown plants that were high in the cis form of the glucoside (14). Thus, slight changes in the configuration of a compound can greatly influence the reaction of an insect to that compound.

\section{Sweetclover Root Borer}

The sweetclover root borer moth [Walshia miscecolorella (Chambers)] may be attracted to coumarin or related compounds. Evidence for this assumption is based on greater numbers of the root borer larvae often being found in high-coumarin cultivars of sweetclover than in cultivars that are low in coumarin (24). Observations were made on root borer infestation in field plantings of nearisogenic lines of sweetclover differing only in content of $o$-HCA and $\beta$-glucosidase activity. In 1969 and 1970 , the plants high in $o$-HCA had significantly higher infestations of the root borer larvae. The presence or absence of $\beta$ glucosidase activity did not influence infestation; thus, the glucosides of $o$-HCA and not coumarin appear to be the responsible substances. Since the larvae developed from eggs deposited by the adult moth and the larvae live exclusively in plant roots and do not readily migrate, it was hypothesized that the differences in infestation resulted from attraction of the moths to $o$-HCA, although differential larval survival could have produced the same result.
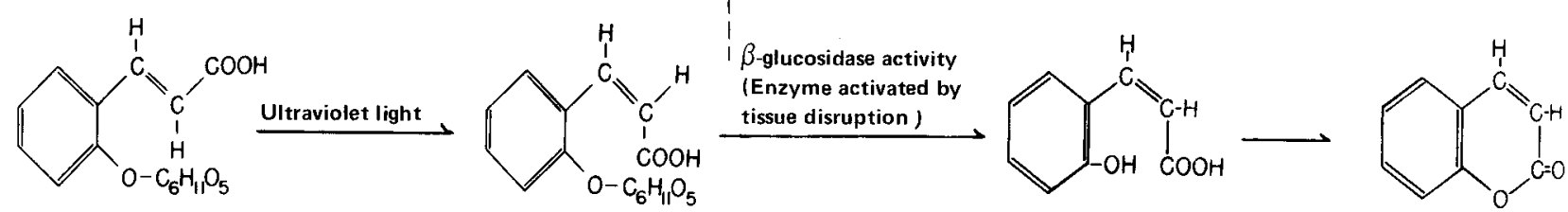

$\beta$-glucoside of trans-ohydroxycinnamic acid
B-glucoside of $\mathrm{Cis}-\mathrm{O}$ hydroxycinnamic acid

Within undisturbed plant tissue

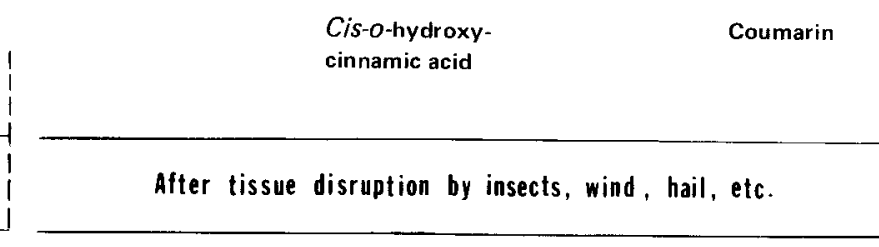

Cis-o-hydroxy-

innamic acid

After tissue disruption by insects, wind, hail, etc.

Fig. 1-Final steps in the biosynthetic pathway leading to coumarin in sweetclover showing the compounds present in undisturbed tissues and the conversions mediated by ultraviolet light and $\beta$-glucosidase activity. 
However, in 1971 when numbers of the insect were greater, significant differences between high and low plants did not exist. If $o$-HCA were necessary for larval survival, greater numbers of insects would not be expected to reduce the differences observed. On the other hand, if the $o$-HCA effect resulted from attraction of the adult moths, the presence of high moth populations would probably reduce this effect. This reduction would be expected because, with high moth populations, random selection of low-o-HCA plants for egg deposition would be expected to increase in frequency, when the high and low-o-HCA plants were in close proximity as they were in all of the field experiments (24).

\section{Sweetclover Weevil}

The adult sweetclover weevil appeared to be attracted to coumarin as evidenced by greater catches in pan traps baited with coumarin crystals (16), but this attractiveness could not be demonstrated in the laboratory. It was therefore hypothesized that coumarin is only attractive when the weevils are in flight (29). 'The lack of attractiveness of coumarin to the weevil in the laboratory has been substantiated (G. R. Manglitz and G. L. Beland, unpublished). Also in the field, coumarin-baited Japanese beetle traps caught more weevils than unbaited traps but only in 1 year out of 3 . Subsequently when $200-\mathrm{mg}$ portions of coumarin crystals were spread on $0.093-\mathrm{m}^{2}$ areas in an alfalfa (Medicago sativa L.) field, sweetclover weevils were attracted to these areas in sufficient number to cause characteristic damage to the alfalfa, though they were not found elsewhere in the field (G. R. Manglitz, G. L. Beland, and W. R. Akeson, unpublished). However, when the same procedure was repeated the following season, no weevils were drawn to the treated areas. Thus, coumarin appears to be attractive to the adult sweetclover weevil, but the exact nature of the attractiveness and conditions that alter attractiveness are not known.

\section{Aphids and Leafhoppers}

Several species of insects that frequent sweetclover appeared not to be influenced by high or low content of coumarin-related compounds. These species are the sweetclover aphid [Therioaphis riehmi (Börner)] (22), the pea aphid [Acyrthosiphum pisum (Harris)] (E. L. Neiman, former graduate assistant, UNL, unpublished), and potato leafhopper [Empoasca fabae (Harris)] (25).

\section{Summary of Coumarin Effects}

Three species of insects do not seem to be influenced at all by coumarin and related compounds. The case of the sweetclover weevil is not complete, but coumarin may act as an attractant. The sweetclover root borer, from circumstantial evidence is attracted to high-coumarin plants, and o-HCA glucoside appears to be the major factor though not all of the facts are known. Four species of blister beetles react to cis-o-HCA glucoside and to coumarin as strong deterrents to feeding that complement each other. Among insects which do not feed on sweetclover, coumarin may attract and deter the same insect. Thus,
Matsumato (26) showed that the vegetable weevil [ Listroderes costirostris obliquus (Klug)], was attracted to sweetclover, a nonhost plant but would not feed on it. He further demonstrated that coumarin was both an olfactory attractant and a feeding deterrent for that weevil.

\section{PLANT SUBSTANCES INFLUENCING FEEDING BY THE SWEETCLOVER WEEVIL}

The second part of this review is centered around a single species of insect, the sweetclover weevil, and the chemical nature of resistance in Melilotus infesta to this insect. Melilotus infesta is the only one of 19 species of Melilotus that is not fed on by the adult sweetclover weevil $(15,23,28)$. Preliminary observations of weevil behavior and plant anatomy indicated that the cause of resistance was probably a chemical deterrent.

\section{Bioassay Method}

The first step in searching for plant substances which influenced feeding was to develop an artificial feeding medium acceptable to the weevil so that substances extracted from the plant could be bioassayed with the weevil. Since the adult weevil feeds on the leaf margins by placing its legs on both leaf surfaces, the medium must be thin (no thicker than a sweetclover leaf), strong enough to support the weevil, and absorbent enough to take up plant extracts.

After many trials, disks cut from the tap root of biennial sweetclover plants in the fall of the first season of growth were found to meet all the requirements. First the disks $(0.1 \mathrm{~mm}$ thick) were cut from suitable sections of sweetclover tap roots with a hand microtone. Then they were washed in water, lyophilized and extracted scparately with ethanol and methanol, and stored under methanol in a freezer until used. Plain disks or disks treated only with water were not consumed by the weevil. Disks treated with an extract from susceptible plants and offered to adult weevils that had been previously confined to disks were readily eaten by the weevils (9).

Various fractions of water-chloroform-methanol extracts of sweetclover leaves were applied to bioassay disks to determine the plant substances that influenced weevil feeding. The chloroform phase from resistant as well as susceptible plants contained a very strong feeding stimulant. This particular stimulant(s) was not investigated further because the major interest was in looking for differences between the resistant and susceptible species. All that can be said about this stimulant is that it does occur in resistant and susceptible plants and is probably a lipid.

Several substances that influenced weevil feeding were separated from the water-methanol phase. Further investigation showed that a similarly active extract could be made with hot water. Hot water extraction had the added advantage of inhibiting any possible enzyme activity in the excised leaves. Fractionation of the hot water extract by paper chromatography revealed the presence of three substances or groups of substances. Stimulant "A" and deterrent "A" were found in resistant and susceptible plants, while deterrent " $B$ " was detected originally only in the resistant species $(5,7)$. 


\section{The Nitrate Ion}

The next logical step was to attempt isolation and identification of deterrent B. Preparative paper chromatography was used in the isolation. Isolated material was eluted from the paper with water and bioassayed against the weevil on root disks previously treated with simulant A. Colorless needlelike crystals were isolated and identified as ammonium nitrate (6). Ammonium nitrate, when applied in the same concentrations as the isolated deterrent, inhibited feeding in the same degree. Further testing indicated that other nitrate salts were equally deterring, thus, the nitrate ion apparently deters feeding regardless of the form in which it occurs. Excised shoots of the susceptible plants, when placed in solutions containing $0.016 M$ sodium nitrate, took up sufficient nitrate ion in 24,48 , and 72 hours to significantly deter weevil feeding (2). The dosage relationship of nitrate-nitrogen to feeding by the sweetclover weevil was determined and from that determination the amount of feeding could be predicted based on the concentration of nitrate ion present. This predicted feeding correlated closely to actual feeding when extracts made from resistant leaflets were assayed for nitrate content and also fed to weevils. However, the weevils would feed on the growing tips of resistant plants, particularly on the newly formed but not yet unfolded leaves. These tightly pinched new leaves were found to contain as little as 100 ppm of nitrate-nitrogen (1). Finally when nitrate-nitrogen was determined in various parts of plants of varying ages, it was found that nitrate content began dropping at 8 weeks of age, and at 12 weeks of age there was very little (usually $<100 \mathrm{ppm}$ ) in any of the leaves. Yet these leaves remained highly resistant to weevil feeding (11). Obviously, other factors must be active in the older plants.

\section{Deterrent A}

Efforts to isolate and identify deterrent A were made with extracts from 20-week-old plants of $M$. infesta because deterrent $\mathrm{A}$ activity was shown to remain high in plants of that age, while the content of deterrent $B$ (nitrate-nitrogen) dropped to a negligible level. After four paper chromatographic separations, deterrent $A$ appeared to be isolated from other interfering plant constituents. The lyophilized fraction retained its deterrent activity when offered to sweetclover weevils in bioassays, but attempts to obtain a crystallized deterrent A from the lyophilized fractions were not successful. Attempts to characterize the lyophilized material indicated that deterrent A probably is a phenolic compound with an amine or other nitrogen-containing group attached either to the ring structure or to a side chain. ${ }^{3}$

\section{Sugars}

Again, preparative paper chromatography was used in the isolation and identification of stimulant $\mathrm{A}$, which proved to be a combination of three sugars (3). Sucrose

\footnotetext{
${ }^{3}$ G. L. Beland. 1972. Biochemical nature of sweetclover plant factors influencing feeding preference by the sweetclover weevil. Ph.D. Thesis. University of Nebraska, Lincoln, Nebr. 73 p.
}

had the most stimulant activity, but fructose and glucose also were present and quite active. When reagent grade sugars were compared to the sugars isolated from sweetclover leaves, the bioassay results were quite similar. In addition, when the amounts of the three sugars in resistant and susceptible plants of various ages were compared, it was found that resistant plants contained less of all three sugars at all ages. Moreover, the sucrose content of the resistant species dropped sharply after the plants reached 11 weeks of age (4). Many other sugars and related compounds were tested for stimulant activity. None was as active as sucrose and very few showed any activity at all, further demonstrating that small changes in chemical composition or structure may greatly change an insect's response (8).

\section{Adenosine}

The report of Hsiao (20) that adenine and related purine compounds acted as feeding stimulants for the alfalfa weevil [Hypera postica (Gyllenhal)] aroused curiosity as to whether similar compounds in sweetclover may also act as feeding stimulants for the sweetclover weevil. Adenine did not stimulate sweetclover weevil feeding, but at a $0.01 M$ concentration, adenosine was equal in stimulating feeding activity to the mixture of the three sugars found in stimulant $\mathrm{A}$ and better than the individual performance of any one of the sugars. This superiority was even greater at lower concentrations. Adenosine was then isolated from hot water extracts of susceptible plants by ion exchange chromatography. Thus, another compound was added to the list of naturally occurring sweetclover weevil feeding stimulants (12).

\section{Summary-Sweetclover Weevil and Plant Substances}

It is evident that numerous substances markedly influence sweetclover weevil feeding. Of the stimulants, the contents of sugars (particularly sucrose) are important in determining the overall level of resistance. Sucrose is of particular importance because of its reduced content in older plants of $M$. infesta. Both of the deterrents probably enter the resistance picture; deterrent $B$ in younger resistant plants and deterrent $\mathrm{A}$ because of its continued presence in older resistant plants.

\section{DISCUSSION AND CONCLUSIONS}

\section{The Coumarin Factor}

Coumarin and its precursors influence the presence and feeding of several species of insects to a degree that makes interesting speculation on what would happen if lowcoumarin sweetclover varieties were grown exclusively over large areas. In small plots where high- and lowcoumarin types are grown in proximity, this possibility is difficult to evaluate. However, it seems reasonable to assume that in a large area where all cultivated sweetclover was of the low-coumarin type, the sweetclover root borer and the sweetclover weevil would tend to concentrate in volunteer high-coumarin plants growing along field margins, roadways, and in other uncultivated areas. Mean- 
while, blister beetles might occasionally become more abundant and damaging in low-coumaring fields. Fortunately, the root borers and weevils are more dependent on sweetclover as a host plant and more closely associated with it on a year-to-year basis than the blister beetles which, in the larval stage, are predaceous on grasshopper eggs, and the adults are most abundant following outbreaks of grasshoppers.

\section{Plant Chemicals and Host Selection}

Coumarin and its related compounds appear to serve no function in the normal growth and development of the sweetclover plant, yet this group of compounds does direct certain species of insects toward or away from the plant. On the other hand, a number of substances (i.e., several sugars, the nitrate ion, and adenosine) also appear to be quite important to the feeding of the sweetclover weevil, but these latter substances may also be very important to the normal development and growth of the plant and some also could be nutritionally beneficial to the insect. It seems a bit curious that such commonly occurring substances could aid the insect in identifying its host plant. Perhaps the answer lies in the fact that a particular combination of a number of these commonly occurring factors is needed by the insect to identify the host plant. Also, different species of insects may respond quite differently to these common substances. The work of Havlicková (19) illustrates this possibility. She reported that maltose and saccharose stimulated feeding in Sitona lineatus L. (a close relative of the sweetclover weevil), but that fructose had no influence and glucose actually inhibited feeding. While some sugars stimulated feeding by the sweetclover weevil, other sugars and related compounds had no activity, and some may even deter feeding (8). Thus, while sugars as a class are common or even universal to plants, specific sugars are not and may be part of the key for insect host finding.

\section{Practical Applications}

Because Melilotus infesta is not cross-compatible with $M$. alba or $M$. officinalis (27) knowledge of the causes of resistance may be of considerable practical importance. That is, if the resistance factor cannot be incorporated by crossing, perhaps it can be added in some other way if we know something of its nature.

It was demonstrated that the addition of nitrate to the sweetclover plant in the laboratory would impart resistance to weevil feeding, and, therefore, it seems reasonable to assume that the same effect could be obtained in the field. In fact, $\mathrm{Kulm}^{4}$, working with field plots and nitrogen fertilizer, found that the control of weevils with fertilizer is technically feasible. However, with a crop of low cash value like sweetclover, perhaps it would be questionable from an economic standpoint.

$\mathrm{Kulm}^{4}$ also observed appreciable plant-to-plant variation in nitrate content within $M$. officinalis, and found that nitrate level was a heritable trait in this species. Thus,

\footnotetext{
${ }^{4}$ R. D. Kulm. 1973. Nitrate content and nitrate reductase activity in Melilotus. M.S. Thesis. University of Nebraska, Lincoln, Nebr. 84 p.
}

it would appear possible to increase the nitrate content of sweetclover by selecting strains with higher than normal levels of nitrate, and using these strains in a breeding program. Kulm also found that the nitrate reductase activity of $M$. infesta was lower than that of $M$. officinalis. This difference in enzyme activity may help to account for the higher nitrate content of $M$. infesta. Increased content of nitrate, whether through breeding or fertilization, would not be desirable when utilizing the crop as forage. However, much of the sweetclover now grown is used for soil improvement and increased nitrate content should enhance the value of the crop for this purpose.

While the nitrate ion was the only one of the resistance factors with demonstrated manipulability in Melilotus, it may be possible also to breed for plants with greater levels of the less attractive or unattractive sugars instead of those which stimulate weevil feeding. An important step in attempting to breed for resistance to insects in any plant species is to identify all of those factors which can be manipulated to advantage. Improved knowledge of the nature of these factors in sweetclover and other crops should further the quest for new and environmentally safe means of controlling plant-destroying insects.

\section{LITERATURE CITED}

1. Akeson, W. R., G. L. Beland, F. A. Haskins, and H. J. Gorz. 1969. Influence of developmental stage of Melilotus infesta leaves on resistance to feeding by the sweetclover weevil. Crop Sci. 9:667-669.

2. Akeson, W. R., G. L. Beland, and G. R. Manglitz. 1969. Nitrate as a deterrent to feeding by the sweetclover weevil. J. Econ. Entomol. 62(5):1169-1172.

3. Akeson, W. R., H. J. Gorz, and F. A. Haskins. 1969. Sweetclover weevil feeding stimulants: Isolation and identification of glucose, fructose, and sucrose. Crop Sci. 9:810-812.

4. Akeson, W. R., H. J. Gorz, and F. A. Haskins, 1970. Sweetclover weevil feeding stimulants: Variation in levels of glucose, fructose, and sucrose in Melilotus leaves. Crop Sci. 10:477479 .

5. Akeson, W. R., H. J. Gorz, F. A. Haskins, and G. R. Manglitz. 1968. A water-soluble factor in Melilotus officinalis leaves which stimulate feeding by the adult sweetclover weevil. J. Econ. Entomol. 61(4):1111-1112.

6. Akeson, W. R., F. A. Haskins, and H. J. Gorz. 1969. Sweetweevil feeding deterrent B: Isolation and identification. Science 163:293-294.

7. Akeson, W. R., F. A. Haskins, H. J. Gorz, and G. R. Manglitz. 1968. Water-soluble factors in Melilotus leaves which influence feeding by the sweetclover weevil. Crop Sci. 80:574576.

8. Akeson, W. R., F. A. Haskins, H. J. Gorz, and G. R. Manglitz. 1970. Feeding response of the sweetclover weevil to various sugars and related compounds. J. Econ. Entomol. 63(4): $1079-1080$.

9. Akeson, W. R., G. R. Manglitz, H. J. Gorz, and F. A. Haskins. 1967. A bioassay for detecting compounds which stimulate or deter feeding by the sweetclover weevil. J. Econ. Entomol. 60(4): 1082-1084.

10. Beck, S. D. 1965. Resistance of plants to insects. Annu. Rev. Entomol. 10:207-323.

11. Beland, G. L., W. R. Akeson, and G. R. Manglitz. 1970. Influence of plant maturity and plant part on nitrate content of the sweetclover weevil-resistant species Melilotus infesta. J. Econ. Entomol. 63(4):1037-1039.

12. Beland, G. L., F. A. Haskins, G. R. Manglitz, and H. J. Gorz. 1973. Sweetclover weevil: Adenosine as a feeding stimulant. J. Econ. Entomol. 66(5):1037-1039.

13. Dethier, V. G. 1954. Evolution of feeding preferences in phytophagous insects. Evolution 8(1):33-54. 
14. Gorz, H. J., F. A. Haskins, and G. R. Manglitz. 1972. Effect of coumarin related compounds on blister beetles. J. Econ. Entomol. 65(6): 1632-1635.

15. Gross, A. T. H., and G. A. Stevenson. 1964. Resistance in Melilotus species to the sweetclover weevil (Sitona cylindricollis). Can. J. Plant Sci. 44:487-488.

16. Hans, H., and A. J. Thorsteinson. 1961. The influence of physical factors and host plant odour on the induction and termination of dispersal flights in Sitona cylindricollis Fåhr. Entomol. Exp. Appl. 4:165-177.

17. Haskins, F. A., and H. J. Gorz. 1961. A reappraisal of the relationship between free and bound coumarin in Melilotus. Crop Sci. 1:320-323.

18. Haskins, F. A., L. G. Williams, and H. J. Gorz. 1964. Light induced trans to cis conversion of $\beta$ - D-glucosyl-o-hydroxycinnamic acid in Melilotus alba leaves. Plant Physiol. 39:777781.

19. Havlið̌ková, H. 1972. Study of the different feeding of Sitona lineatus in lentil and vetch. (In Czechoslavakian with English summary.) Proc. 4th Nat. Conf. on Plant Prot., Bratislava. Part II:83-90. Cent. Res. Inst. for Plant Prot., Dep. of Entomol., Prahag, Czechoslovókia.

20. Hsiao, T. H. 1969. Adenine and related substances as potent feeding stimulants for the alfalfa weevil, Hypera postica. J. Insect Physiol. 15:1785-1790.

21. Kosuge, T., and E. E. Conn. 1961. The metabolism of aromatic compounds in higher plants. III. The $\beta$ glucosides of o-coumaric, coumarinic, and melilotic acids. J. Biol. Chem. 236:1617-1621.

22. Manglitz, G. R., and H. J. Gorz. 1961. Resistance of sweetclover to the sweetclover aphid. J. Econ. Entomol. 54(6): $1156-1160$.

23. Manglitz, G. R., and H. J. Gorz. 1964. Host-range studies with the sweetclover weevil and the sweetclover aphid. J. Econ. Entomol. 57:683-687.

24. Manglitz, G. R., H. J. Gorz, and F. A. Haskins. 1974. Resist ance in sweetclover to the sweetclover root borer. USDAARS-NC-1 8. 3 p.

25. Manglitz, G. R., and J. L. Jarvis. 1966. Damage to sweetclover varieties by potato leafhopper. J. Econ. Entomol. $59(3): 750-751$

26. Matsumoto, Y. 1962. A dual effect of coumarin, olfactory attraction and feeding inhibition, on the vegetable weevil adult, in relation to the uneatability of sweetclover leaves. Studies on the host plant determination of the leaf-feeding insects. VI. Jpn. J. Appl. Entomol. Zool. 6(2):141-149.

27. Ojomo, O. A., and H. J. Gorz. 1966. Studies of interspecific sterility mechanisms in species of Melilotus. Niger. Agric. J. $3(2): 76-79$.

28. Radcliffe, E. B., and F. G. Holdaway. 1967. Sweetclover weevil resistance in Melilotus Adams, Medicago L., and Trigonella L. Minn. Agric. Exp. Stn. 'Tech. Bull. 255. 26 p.

29. Thorsteinson, A. J. 1960. Host selection in phytophagous insects. Annu. Rev. Entomol. 5:193-218. 